\title{
Harnessing marine renewable energy from Poole Harbour: a case study
}

\section{Tilak Ginige*}

School of Applied Sciences,

Bournemouth University,

Poole, BH12 5BB, UK

E-mail: tginige@bournemouth.ac.uk

*Corresponding author

\section{Frazer Ball}

Business School,

Bournemouth University,

Bournemouth, BH8 8EB, UK

E-mail: fball@bournemouth.ac.uk

\section{Jane Butters, Catherine Caine, Stanford Julius and David Pearce}

\author{
School of Applied Sciences, \\ Bournemouth University, \\ Poole, BH12 5BB, UK \\ E-mail: janebutters@talktalk.net \\ E-mail: c.a.caine@newcastle.ac.uk \\ E-mail: Stanford Julius j-sb@hotmail.co.uk \\ E-mail: David Pearce sharkydave76@yahoo.co.uk
}

\begin{abstract}
Global warming and its impact on our environment, society and economy is one of the fundamental concerns of our time. In response, the UK Government has implemented numerous targets including the $80 \%$ reduction in greenhouse gas emissions on 1990 levels by 2050, and the increase of renewable energy to $15 \%$ by 2020 . In order to contribute towards these targets, the government may seek to harness the UK's high marine and coastal renewable energy potential. Located in Southwest England, Poole Harbour provides strong potential for producing reliable tidal and heat energy. However, due to the special nature of Poole Harbour, construction in this area may result in conflicts of a social, economic and environmental nature. The purpose of this article is to examine the Poole Harbour case study in order to provide an analysis of the conflicts that arise between the use of renewable energy and the need to safeguard ecosystems.
\end{abstract}

Keywords: community; economics; environmental law; renewable energy; spatial planning.

Reference to this paper should be made as follows: Ginige, T., Ball, F., Butters, J., Caine, C., Julius, S. and Pearce, D. (2013) 'Harnessing marine renewable energy from Poole Harbour: a case study', Int. J. Liability and Scientific Enquiry, Vol. 6, Nos. 1/2/3, pp.1-26. 
Biographical notes: Tilak Ginige is a Senior Lecturer of Environmental Law at Bournemouth University's School of Applied Sciences. He is a member of the UK Environmental Law Association and the Nordic Environmental Law, Governance and Science Network. He has in the past contributed to the Catalan Government's Environmental Policy. His other research-related achievements include involvement in EU funded research concerning the Water Framework Directive and the EU Mining Waste Water Directive. He has published in refereed journals including the European Environmental Law Review, Law Environment and Development Journal (LEAD), the Journal of Water Law and Int. J. Liability and Scientific Enquiry. He participated in a multidisciplinary renewable project energy with local community involvement, which looked at Poole Harbour as a potential source of green energy. He is a member of the Business School's Sustainable Energy Research Group.

Frazer Ball is a Senior Lecturer of Accounting and Finance at the Business School, Bournemouth University, specialising in risk/disaster management and financial modelling. In addition to undertaking a $\mathrm{PhD}$ within the field of financial and alternative investments, his research currently focuses on the economic and multi-disciplinary aspects of renewable energy projects. As the UK strives to meet national obligations for the generation of energy from low carbon sources in order to create affordable energy security, the analysis of energy projects from economic, legal and environmental perspectives provides a balanced assessment of future proposals. He is a member of the Business School's Sustainable Energy Research Group.

Jane Butters is an Independent Researcher and former Visiting Fellow at the School of Applied Sciences, Bournemouth University. She is a Spatial Planner with over 30 years of professional experience in policy making and implementation in both local government and private practice. She previously taught spatial planning, environmental management and development issues on a range of courses in the Schools of Conservation Sciences and Service Industries, Bournemouth University. Her current research interests are focused on the evolving spatial planning system in England, the monitoring of its outcomes, its efficacy in the sustaining and enhancing of biodiversity and its role in the transition to a sustainable energy system.

Catherine Caine is currently reading LLM Environmental Law and Policy (Research) at Newcastle University after graduating from Bournemouth University with a first class honours LLB degree. Her current research interests lie in sustainable development, the construction of renewable energy projects and climate change law. Her current research concerns the proposed offshore wind farm construction at Dogger Bank, which aims to form part of a larger research project within the UK that will analyse the legal mechanisms employed in the construction of a renewable energy project and the extent to which they protect the existing environment.

Stanford Julius graduated from Bournemouth University with a BSc (Hons) in Environmental Forensics. He has been involved in various projects under a local authority, within the Waste Management Department and is currently working as a Carbon Management Officer. His research interests lay in sustainable development, social justice and renewable energy, specifically the environmental risk element of infrastructure projects.

David Pearce graduated from Bournemouth University with a first class degree in Environmental Protection and Management (BSc), and was awarded the Environment Agency prize for best environmental student. Since graduating, he has continued to work with Bournemouth University staff, and has a particular 
interest in marine invasive species and how marine renewable energy projects may influence their spread through the alteration of ecological and physical processes.

\section{Introduction}

The global commitment to renewable energy and energy security stems from the application of Bentham's utilitarian philosophical perspective of "the greatest good for the greatest number" (Presnell, 1996; Bentham, 1907). By securing energy obtained from naturally occurring elements within the biosphere, e.g., from the sun, the wind and the oceans, we are attempting to prevent further deterioration of natural and cultural resources. In doing so, we are aiming to pass on to our descendants a better world, or at least in as good condition as the one we ourselves inherited (Weiss, 1984). This perspective was supported by Brundtland who stated that future development crucially depends on the long-term availability of energy "in increasing quantities from sources that are dependable, safe and environmentally sound" (UNWCED, 1987). However, the report recognised as well, that harmful ecological transformation may occur as a consequence of the technology required to harvest natural sources, citing as an example the problems encountered in hydropower where hydrodams block paths for migrating fish (UNWCED, 1987).

The precautionary principle 15 of the Rio Declaration 1992 (Rio Declaration on Environment and Development, 1992) addresses this danger by suggesting a positive obligation on regulators to act to prevent the materialisation of health or environmental risks, despite the lack of scientific certainty over the nature or extent of the ecological transformation. The existence of scientific uncertainty should become a trigger for precautionary measures, and for 'reversing the onus of proof' so that proponents, rather than regulators, bear the burden of demonstrating that there is no need for regulatory action (Peel, 2004).

The European Union (EU) and the UK have adopted the precautionary principle as one of their guiding environmental policies. The UK Climate Change Policy introduced this principle with legal, economic and technological enabling mechanisms to reduce green house gases in the UK (Jordan and O'Riordan, 1995). Following recommendations from the UK Committee on Climate Change, the Department of Energy and Climate Change (DECC) (2012) has put forward policies to achieve 30\% of electricity generation from renewable sources by 2020, aiming further than the EU $15 \%$ target. To meet these targets, the DECC has indicated that $7.5 \%$ needs to be delivered from local sources (DECC, 2012). In response to this, local authorities are embarking on their own strategies to achieve these objectives.

One such strategy has been approved in the southwest of England between Dorset County Council, the Borough of Poole Council and Bournemouth Borough Council. This strategy is known as the 'Renewable Energy Strategy to 2020' (DEP, 2012) and aims to harness viable renewable energy resources to maximise local economic, environmental and community benefits (DEP, 2012).

Poole Harbour is the one of largest natural saltwater harbours in the UK. It represents a highly predictable tidal and heat energy potential that has prompted local interest in 
investigating the possibility of harnessing it for the benefit of the area through community schemes (Cooling, 2011). At the same time, Poole Harbour has a variety of marine, freshwater and terrestrial habitats which, together with surrounding Areas of Outstanding Natural Beauty, are subject to a number of statutory and non-statutory designations. The proposal to harness marine renewable energy from Poole Harbour will provide an insight into the different challenges faced by Community Renewable Energy (CRE) schemes. These include ecological, legal, economic and planning issues that need to be factored in order to achieve climate change mitigation without loss of biodiversity.

\section{CRE projects}

Alternative methods of energy production are available on both large and small scales (Miller, 2006). However, it is considered that small scale, community-based renewable energy schemes are better able to meet the precautionary principle (Poladitis et al., 2006). It has also been proposed that small scale schemes are more likely to fit in with the doctrine of sustainable development, as local interested parties will use their understanding of local needs and their natural environment to propose sensible precautionary measures (Dincer, 2000). From their agreeance with the precautionary principle and the principle of sustainable development, it can be argued that CRE projects are an innovative and successful way to supply energy to homes and businesses on a small scale with a range of associated benefits for local people and ecosystems (Rogers et al., 2012). Although this concept is not particularly new, with a few communities beginning to adopt this ethos from the 1970s (Walker, 2008), it is in more recent years that interest has risen in CRE as a way to produce energy with much reduced environmental cost. This wider interest, together with the advances in technology to generate secure and financially viable renewable energy, has led to a significant increase in the number of community driven projects (Department of Trade and Industry, 2000). The aim is to provide locally-based, renewable, secure energy supplies with an emphasis on community participation, ownership and a green ethos (Rogers et al., 2012).

As each community and locality differs from the last, there is no set framework or protocol for CRE projects (Rogers et al., 2008). Each one is unique, according to site, community vision and choice of technology (Shackley and Green, 2005). Nevertheless, common features amongst these schemes are: the existence of a set of values shared by all involved and that, according to research on public perceptions, local communities find these projects desirable (Rogers et al., 2008).

\subsection{The Poole Tidal Energy Partnership: background and technical detail}

The Poole Tidal Energy Partnership (PTEP) was formed on 4th November 2011 in response to local policies on renewable energy (E-mail from Hadley, 2012b). This partnership, with participants from the Borough of Poole, Transition Town Poole and Bournemouth University, combines local knowledge, community representation and technical expertise to form a single organisation focussed upon driving forwards the vision of a local, secure and green energy supply. PTEP's aim is to provide renewable energy at affordable prices to local residents whilst encouraging a high degree of community participation in the project. 
PTEP initially proposed to employ underwater turbine technology to power a water source heat pump (WSHP) system that could provide heat energy to residents living within the immediate area (Julius, 2012). However, the tidal current prototype generator was ruled out because the depth of the water in Poole Harbour $(1-5 \mathrm{~m})$ did not meet the requirements for cost-effective power generation (20-30 m) (Turnpenny et al., 1995; DEP, 2012). It was then suggested that a WSHP, without the turbine technology, might be the most viable technology for this harbour. This could be implemented either as a closed or open loop system (E-mail from Hadley, 2012a) and both are currently under consideration.

Figure 1 Closed-loop WSHP (see online version for colours)
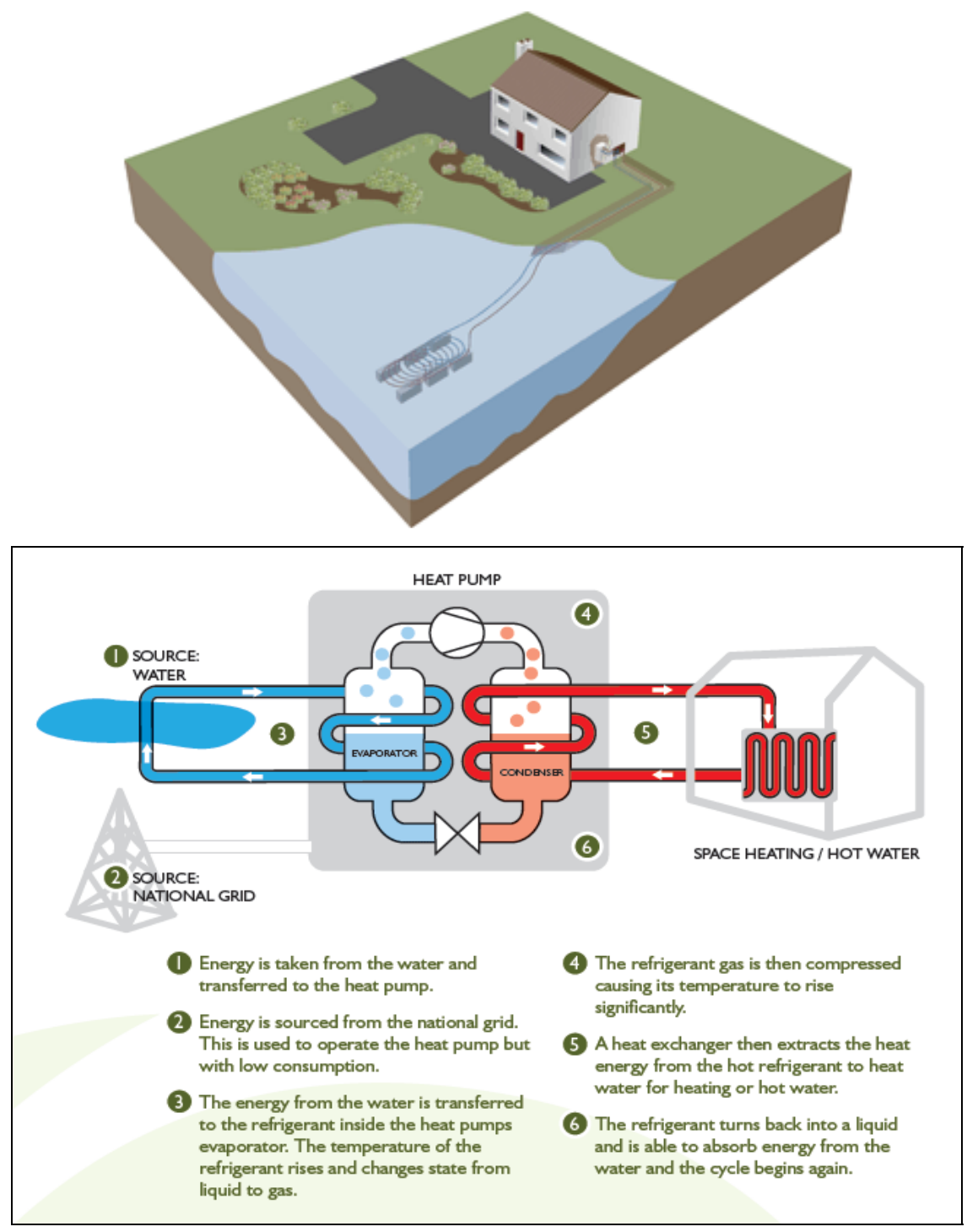

Source: Forsen (2005) 
A closed-loop system (see Figure 1) employs a fluid (food grade glycol and water mix) that circulates within a submerged coil of flexible pipework which absorbs energy from the surrounding water (Forsen, 2005). A sufficient depth is required to prevent freezing around the pipework and any damage from passing marine traffic (Kensa Engineering Ltd., 2009).

An open source system (see Figure 2) draws in water out of the harbour, passing it through the heat pump and then discharges it back into the harbour (Forsen, 2005). This brings into consideration associated issues of corrosion, filtration, extraction and possible freezing within the heat exchanger (Forsen, 2005).

Figure 2 Open loop heat pump (see online version for colours)

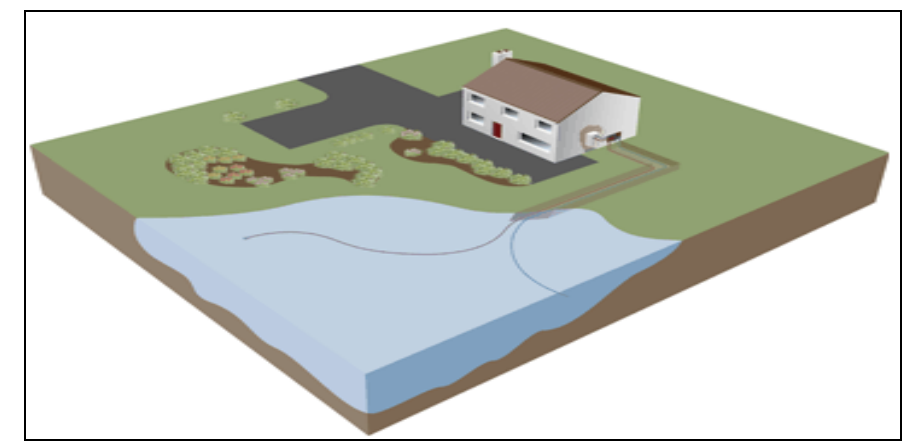

Source: Forsen (2005)

\section{Economics}

As both a fundamental concern to both society and the principle of sustainable development, it is important for the scheme at Poole Harbour (along with all CREs) to consider the economic benefits and disadvantages of development. The UK Renewable Energy Roadmap sets out actions to help meet the above mentioned targets to generate energy from renewable sources and focuses on eight different technologies which "have either the greatest potential to help the UK meet the 2020 target in a cost effective and sustainable way, or offer great potential for the decades that follow" (DECC, 2011a).

The eight technologies identified are: onshore wind, offshore wind, marine energy, biomass electricity, biomass heat, ground and air source heat pumps, and renewable transport (DECC, 2011a). Government Ministers believe that the UK has "the best wind, wave and tidal resources in Europe" (DECC, 2011a). Significant opportunities exist for the UK to make the most of its island geography and harness the power of its coastline in the production of low carbon energy.

In November 2011, the government launched the renewable heat incentive (RHI) scheme to provide "financial support to non-domestic renewable heat generators" (DECC, 2011b). This seeks to provide a 20 year income stream to those who install a system covered under the scheme with the aim of making renewable heat an attractive commercial option. Renewable heat is simply any heat generated from a renewable source and will include the use of ground and water (marine) source heat pumps. 
Gazo et al. (2011) identify heat pumps as being the largest worldwide application for direct use geothermal energy, with worldwide utilisation in 2010 of $214,780 \mathrm{TJ} / \mathrm{yr}$ (59,632 GWh/yr). The government has set aside $£ 680 \mathrm{~m}$ for use between 2011 and 2015 to fund the RHI scheme (DECC, 2011b), with the amount payable to each scheme being dependent on the amount of heat generated. Non-domestic heat generation would include schools, businesses, hospitals and district heating schemes.

An international example of non-domestic, direct use, marine-source heat pumps can be seen off the coast of Sundsvall, Sweden, where the organisation Permobil AB. has laid $5,000 \mathrm{~m}$ of looped piping on the sea bed. This pipework links to four $30 \mathrm{~kW}$ heat pumps, sufficient to provide heating for $3,300 \mathrm{~m}^{2}$ of the organisation's facilities with only an occasional need for 'top-up' power (NIBE, 2012).

In the UK, the National Trust is currently working with Bangor University to investigate the possibility of using marine-source heat pump technology to reduce the energy costs of the mansion Plas Newydd on the Isle of Anglesy (Jones, 2011). The proposed installation of a large-scale closed-loop system on the bed of the Menai Straits off the coastline has the potential to save $£ 65,000$ p.a. (Guardian, 2012).

Within Poole Harbour the opportunities for direct use geothermal energy production are currently being explored, through the use of marine-source heat pumps in a number of locations, to provide heat to a number of sites, which may be eligible for government support under the RHI.

The potential locations that have been identified are as follows:

a Sterte Court - (Poole Housing Partnership flats)

b Upton Country Park - (tearooms rather than main house)

c Hamworthy Schools - (Carter Community, Hamworthy First and Hamworthy Middle)

d Rockley Park (caravan park and communal buildings)

e Hamworthy Library (potentially this and other local buildings)

f RNLI headquarters.

g Poole Harbour Redevelopment area.

It is proposed that these sites may be suitable for the direct use geothermal energy produced via either closed or open loop WSHP systems.

Whilst there are planning and environmental concerns regarding such development in Poole Harbour, economic considerations must feature strongly in any analysis regarding the viability of such a project.

A series of evaluation methods could be employed to appraise the merits of the proposed Poole Harbour scheme. Cost/benefit analysis incorporating net present value (NPV); internal rate of return (IRR) or payback analysis could be employed to assess financial viability. When using discounted cash flow (DCF) techniques such as NPV and IRR, future cash flows are discounted (using an appropriate discount rate) to present value. This allows comparison between alternative options and those producing a positive NPV classed as financially viable.

The first issue would be in determining an appropriate discount rate, as previous large-scale energy projects (such as evaluations of the Severn Tidal Barrage scheme or 
proposed nuclear development within the UK) have produced wide ranging forecasts resulting from assumptions over the discount rate (Ginige et al., 2011). The standard government approach in the UK is to use 3.5\% (HM Treasury, 2011) for evaluating projects requiring central government funding. However, for projects requiring private finance, example $10 \%$ discount rates have been applied (DECC, 2010) but in reality, private investor's own cost of capital would determine overall viability.

A typical NPV analysis may offset discounted monetised costs and benefits against each other to provide the 'net' result. The question arises of the monetised costs to be included in such analysis.

Kavanaugh et al. (1995) cited Gazo et al. (2011) breaks down the cost of a direct use geothermal heat pump system. The capital costs, which for many renewable (or low carbon) energy projects are the most expensive element, consist of:

a Ground loop $=$ up to $34 \%$ of cost

b Heat pump $=$ up to $30 \%$ of cost

c Indoor installation $=$ up to $21 \%$ of cost

d Ductwork $=$ up to $15 \%$ of cost

e Pumps $=$ up to $7 \%$ of cost.

Gazo et al. (2011) suggest that although capital costs are higher than most other forms of conventional heating, low operational costs result. In addition, the type of system used can affect the capital costs. A vertical closed-loop system (typically used in a ground source heating installation where the available land area is limited) will require pipework to be drilled underground and therefore becomes far more expensive than a horizontal loop system (which requires no drilling). However, although a closed-loop horizontal system may have 50\% lower capital costs, Gazo et al. (2011) explain that "for large installations, it may be impossible to find adequate areas for the installation".

A site such as Poole Harbour, given the size and flat nature of the harbour bed may be suitable for horizontal loop systems (here utilising marine-source heat pumps) and therefore allow localised heat generation to be gained at a reduced capital cost, alongside the benefits of lower operational cost.

In addition to capital, operational and maintenance costs, the level of compensation for the habitat affected will potentially need to be factored into the calculations. As an indication of this cost, compensatory habitat was provided for at $£ 72,000 /$ ha during the Feasibility Study for the Severn Barrage (DECC, 2010). Furthermore, costs of mitigating undesirable environmental effects may need to be considered.

These costs could be offset against key monetised benefits, which may include the "avoided capital investment in other technologies and avoided running costs of other technologies" (DECC, 2010) or the potential savings in energy costs, which Gazo et al. (2011) report as being between $30 \%$ to $60 \%$ for domestic systems. Further economies of scale may result for larger scale non-domestic systems.

Energy cost savings will in part be affected by the efficiency of the heat pumps. Gazo and Lind (2010) explain that this efficiency is measured by the coefficient of performance (COP). The COP measures the amount of energy produced by the heat pump in heating mode, divided by the amount of energy required to drive the heat pump (Gazo and Lind 2010). 


$$
\mathrm{COP}=\frac{\text { Heat capacity }(\mathrm{kW})}{\text { Electric power input }(\mathrm{kW})}
$$

The heat pumps to be used in Poole Harbour are expected to have a very efficient COP of $5: 1$.

When evaluating such a project purely from an investor perspective, giving consideration only to direct, monetary values, Woodruff $(2007$, p.18) states that "a project is financially viable when a project's revenues exceeds its costs". However, Woodruff (2007) contrasts this with an economic approach, where both direct and indirect, monetary and non-monetary costs and benefits are considered. Clearly, economic analysis from a societal perspective provides a much wider scope of factors to be considered and may lead to contrasting results. Using this economic approach, Woodruff (2007) advises "the project with the greatest net benefits should be chosen among all technologically feasible options for providing electricity....".

Considering an economic approach to the evaluation of renewable energy projects, key non-monetised costs and benefits may need to be incorporated into the analysis. However, the difficulty here is that these are difficult to quantify. Air or noise pollution during construction may be a consideration but perhaps the greatest non-monetised cost is the potential effects on the ecosystem within the harbour and beyond. The impact on and valuation of ecosystem services is a consideration which must form part of the appraisal of future energy projects in general and especially in a project where the site is as significant as Poole Harbour. These non-monetised costs may be countered by non-monetised benefits, such as macroeconomic benefits for the UK as a whole (DECC, 2010) through the use of renewable energy and contribution towards EU energy targets. However, whether on balance this leads to a net benefit, and to whom, is the subject of much debate, and is dependent on the valuation of these non-monetised costs and benefits.

\section{Poole Harbour ecology}

As noted, Poole Harbour is an area of significant environmental importance. In order to appreciate the impact that the PTEP project in Poole Harbour, an understanding of the geological features and ecological importance of the area is imperative.

Poole Bay is a drowned valley (ria) that was formed at the end of the last ice age. The bay is an estuary formed from a number of rivers, the largest of which is the River Frome, and is surrounded by shallow creeks and islands (Humphreys and May, 2005). Poole Harbour, located to the west of Poole Bay, is one of the largest natural harbours in the UK, and which has a shallow water depth of approximately 1 to 5 metres. The depth of the bay is between 5 and $20 \mathrm{~m}$ and has a gradually shelving sandy bottom (Turnpenny et al., 1995). Its micro-tidal regime results in the retention of a significant body of water throughout the tidal cycle; with a spring tide range of $1.8 \mathrm{~m}$ and a neap tide range of $0.6 \mathrm{~m}$. Twice a day, between " 30,400 to 45,000 cubic metres of water enters and leaves Poole Harbour", offering huge potential for the implementation of marine renewable projects (Cooling, 2011). Another relevant feature of the Harbour is the unique inter-tidal habitats which have resulted in the area being internationally important for populations of breeding and migratory bird species (Herbert et al., 2010). 
The Harbour is a heavily utilised and managed site covering an area of approximately 3,600 ha (Humphreys and May, 2005), with the densely populated north side of the harbour serving the town of Poole (Poole Harbour Aquatic Management Plan, 2011). There are local management schemes that aim to keep disturbance in the area to a minimum, particularly in bird sensitive areas between Studland Bay, at the entrance of the Harbour, and Keysworth Point, to the west (Poole Harbour Aquatic Management Plan, 2011). The Poole Harbour Aquatic Management Plan, overseen by the Poole Harbour Steering Group, advocates zoning, as shown in Figure 3, to "assist in the reduction of disturbance to environmentally sensitive areas". The plan's main objective is "to promote the safe and sustainable use of Poole Harbour" whilst balancing the competing demands of user groups (Poole Harbour Aquatic Management Plan, 2011).

Figure 3 Map showing the approximate extent and location of the intertidal habitats of Poole Harbour (see online version for colours)

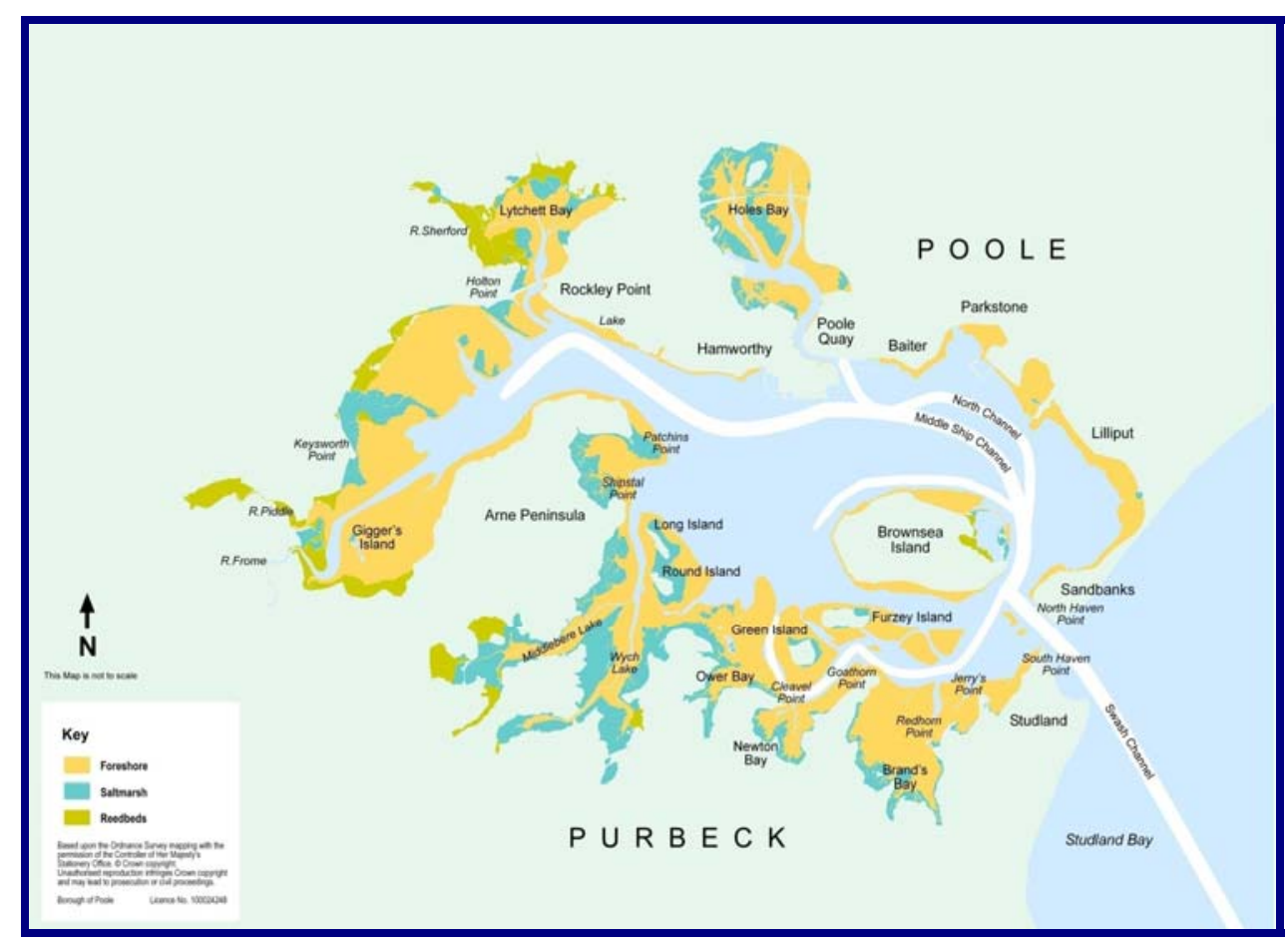

Source: Poole Harbour Aquatic Management Plan (2011)

Due to the variety of important marine, freshwater and terrestrial habitats of conservation interest located within Poole Harbour, the area is subject to a number of statutory and non-statutory designations (MMO, 2012). As an internationally acclaimed site for avifauna, supporting populations of birdlife year round, the intertidal mudflats, reed beds and salt marshes bordering the harbour are important feeding and breeding sites for these species (Natural England, 2010). The harbour supports internationally significant populations of black-tailed godwit (Limosa limosa) and large numbers of dunlin (Calidris 
alpine), redshank (Tringa tetanus) and curlew (Numenius arquata) (Durell et al., 2006). In addition, a number of islands are located within the harbour: Brownsea Island and lagoon, Long Island, Furzey Island, Green Island and Round Island. They all provide habitat for a diversity of coastal and terrestrial species including the avocet (Recurvirostra avosetta), spoonbill (Platalea leucorodia) and red squirrel (Sciurus vulgaris) (Langston et al., 2003). Furthermore, adjacent to the harbour are several nature reserves; Upton Heath, Arne, and Holton Heath, which are highly regarded nationally and internationally for supporting healthy populations of rare native reptiles, birds, insects and plant life (Natural England, 2010).

Anthropogenic activities in the marine environment within the harbour include heavy freight and bulk movements, tourism and leisure activities, and fishing. Many of these contribute to the presence of invasive species (Pearce, 2012). Furthermore, dredging of one shipping channel to facilitate access to the harbour takes place on a regular basis (Poole Harbour Commissioners, 2011). These activities are already a constant threat to its conditions and features (Natural England, 2010).

The impacts of novel structures required by any renewable energy project into marine environments are largely unknown (Polagye et al., 2011). However, in the case of the PTEP proposal it is possible to forecast some degree of disruption to species movements and migrations, alteration of benthic habitats, contamination from paints/lubricants, injury through collision of being struck by the energy generating technology, alteration of currents/water movement, increased noise through installation and operation of technology, and the cumulative impacts of all of these stressors (Polagye et al., 2011) in addition to the existing ones. Therefore, very careful planning would be required to avoid detrimental consequences to this site which is supporting nationally and internationally protected species and habitats (Liley and Clarke, 2003).

\section{Environmental legislation}

The overarching legislation in the UK that regulates development on land and in marine environments, including the activities of renewable energy projects, is the spatial planning legislation. The Town and Country Planning Act 1990 and the Marine and Coastal Access Act 2009 are the principal acts for terrestrial and marine areas respectively. Spatial planning legislation has two main statutory levers: forward policy and programme making and the control and shaping of development proposals through the granting or refusal of planning permissions (Crawford and French, 2008) or licences, in the case of marine developments. For the PTEP project to be able to proceed, it must acquire consent under spatial planning legislation from the appropriate authority whose determination will be guided by spatial development plans and related policy documents. (This issue will be discussed further in Section 6).

Additionally, due to its recognised ecological importance, any development in Poole Harbour needs to take into consideration certain international conventions, European and UK marine and nature conservation laws, as well as water quality legislation. This results in a complex environmental legal framework that gives several layers of protection, sometimes from different points of views, to the same site. The most relevant legislation with regard to Poole Harbour will be discussed below. 


\subsection{Nature conservation legislation}

At an international level the UK is a signatory to the Convention for the Protection of the Marine Environment of the North East Atlantic adopted 22 September 1992, entered into force 25 March 1998 (OSPAR Convention). According to Art. 1 of the Convention, Poole Harbour and the sea adjacent to it comes within the remit of Region II Greater North Sea. Therefore, under Art. 2(1)(a) UK has a duty 'to take all possible steps to prevent and eliminate pollution and shall take the necessary measures to protect the maritime area against the adverse effects of human activities so as to safeguard human health and to conserve marine ecosystems and, when practicable, restore marine areas which have been adversely affected. To this end, the UK is required to adopt measures to tackle pollution and prevent degradation of this marine and costal environment. An expression of the application of these measures at local level is seen in the Poole Harbour Aquatic Management Plan created by the Poole Harbour Steering Group (Poole Harbour Aquatic Management Plan, 2011).

The UK also ratified the Convention on Wetlands of International Importance, 1971 (Ramsar Convention) in 1976. This convention imposes a general duty to promote the conservation of wetlands and waterfowl. 'Wetlands' are defined as 'areas of marsh, with water that is static or flowing, fresh, brackish or salt, including areas of marine water whose depth does not exceed $6 \mathrm{~m}$ '. Due to their ecological importance, parts of Poole Harbour were designated a Ramsar wetland site in 1999 (JNCC, 2008).

In England, all terrestrial areas included within listed Ramsar sites are currently sites of special scientific interest (SSSI). They are legally protected under the Wildlife and Countryside Act 1981 as amended. Poole Harbour was first designated as a SSSI in 1964 under the National Parks and Access to the Countryside Act 1949 12, 13 and 14 GEO. 6. CH. 97 (English Nature, 1990) to protect its intertidal and coastal habitats. It is protected under the provisions of Part II of the Wildlife and countryside Act 1981 SI 1982 No. 1217 (C 39) as substituted by Schedule 9 of the Countryside and Rights of Way Act 2000. 2000 c. 37 (CRoWA 2000). As a result, all public bodies are required to take reasonable and consistent steps with the proper exercise of their functions, in order to protect the conservation features of the SSSI. The legislation also places legal obligations on owners and occupiers of the land within the SSSI and also to any person in relation to activities that may cause damage to its special features or recklessly disturb any animal of special interest.

Section 28 of Wildlife and Countryside Act 1981 as substituted by Schedule 9 of the CRoWA 2000, further outlines the responsibilities and obligations of public and statutory bodies when carrying out activities or authorised works within a SSSI. There is a list of operations and activities likely to damage the features of special interest of Poole Harbour SSSI, which can be obtained from natural England. The owner or occupier of land within a SSSI can only allow these activities to occur on their land with the consent of Natural England.

At European level the oldest nature conservation legislation is the Council Directive 2009/147/EC on the Conservation of Wild Birds (EU Birds Directive). Member states designate special protection areas (SPA) to conserve the birds listed in Annex 1 of the Directive, including migratory birds. The SPAs are also classed as Natura 2000 sites, which form part of a European network of protected sites.

In 1999, parts of Poole Harbour were designated SPA due to the internationally important assemblages of waterfowl and populations of certain regularly occurring 
resident and migratory species (Humphreys and May, 2005). These species are protected by Art. 4 of the Council Directive 79/409/EEC on the Conservation of wild birds (the first Birds Directive consolidated later in the one mentioned above) and are listed in Annex II of Council Directive 92/43/EEC on the conservation on natural habitats and of wild fauna and flora (EU Habitats Directive) and the relevant site assessment.

Under the UK Conservation of Habitats and Species Regulations 2010-SI 2010 No. 490, the EU Habitats Directive forms the basis for the protection and management of the SPA (see Figure 4). The part of the SPA which covers the intertidal zone of the Harbour is referred to as a European Marine Site (EMS). Any activity classed as a high risk will require additional management measures to avoid deterioration and disturbance in line with the obligations under Art. 6(2) of the EU Habitats Directive (European Commission, 2000).

Figure 4 Map of Poole Harbour showing SSSI and SPA boundaries (see online version for colours)

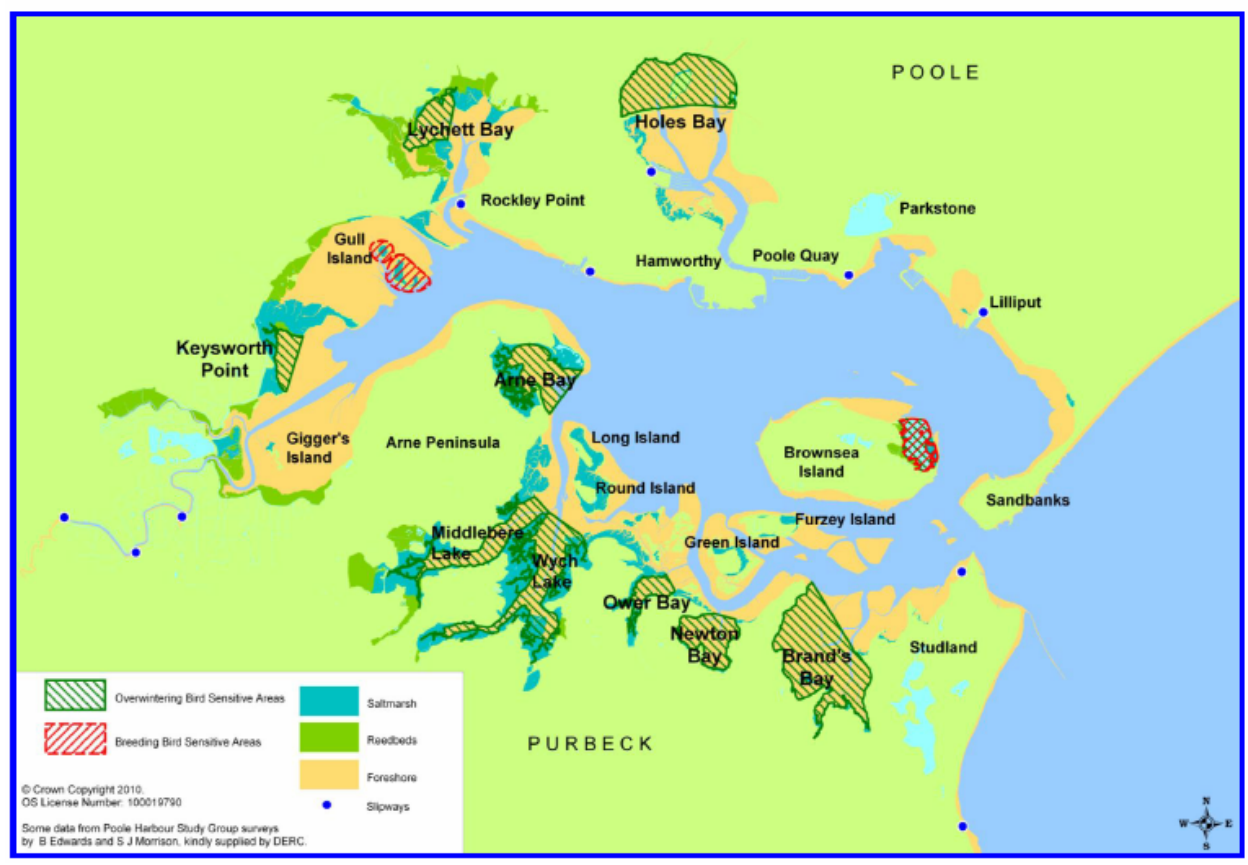

Source: Poole Harbour Aquatic Management Plan (2011)

As discussed above, the Birds Directive and Habitats Directive impose a duty on member states to protect SPAs and is directly applicable to Poole Harbour. However, whilst providing protection for SPAs, the latter also provides member states with the power to permit development on protected sites in certain circumstances. Article 6(4) of the Habitats Directive states that a project may go ahead if there are no alternatives and there is an overriding public interest, including socio-economic factors. Furthermore, the guidelines to the Directive state that whilst development on a protected site, particularly one with vulnerable species, is not ideal in cases where public safety or immediate 
environmental protection are a necessity, plans or projects may still go ahead (Kramer, 2009).

In some proposed plans, these guidelines have been subjected to significant criticism because they seem to override the nature conservation issues in favour of the socio-economic benefits. However, there are examples of opposite outcomes with regard to projects with potential detrimental impact on the environment. On the one hand, in 2003 the Dibben Bay Appeal showed that nature conservation interest were given a higher status than the economic and social interests because the proposed cargo terminal in Dibden Bay would damage the integrity of the Solent and Southampton Water Ramsar site, the SPA and other surrounding protected areas. On the other hand, in the feasibility study for a tidal energy project in the Severn Estuary, the government gave more importance to economic and the energy generation potential over the detrimental environmental impacts to the nature conservation sites. The final reason for the plan not being implemented was that the scheme did not appear cost effective (Ginige et al., 2011).

Another important aspect within the discussion of nature conservation law is the concept of cumulative impacts. This refers to the consequence of more than one direct or indirect impacts acting together, resulting in an outcome difficult to predict, with indirect consequences manifesting in unexpected places and after of a period time (Barrow, 2006). Different laws take this concept into consideration.

Council Directive 2011/92/EU (Directive 2011/92/EU (OJ L 26, 28.1.2012, p.1) codifies Directive 85/337/EEC and its three subsequent amendments (Directives 97/11/EC, 2003/35/EC and 2009/31/EC) (EU EIA Directive) establishes the circumstances when an Environmental Impact Assessment (EIA) is required. The Habitats Directive Art. 6(3) also includes a requirement to conduct another appropriate assessment if the plan or project, either individually or in combination with other plans or projects, has the potential to significantly affect the integrity of a Natura 2000 site. It is suggested that the provisions found in these directives provide clear instructions about what must be considered, referring specifically to the requirement to use best available techniques, the need to identify all potential impacts (including cumulative ones), and the most effective mitigation measures must also be discussed (Kramer, 2009). However, despite the provision in these directives about the considerations required to be included in the assessments (Kramer, 2009), it is apparent that there is confusion on the part of EIA practitioners regarding the definition of cumulative impacts and their specific requirements (Masden et al., 2010). Particular uncertainty arises within the UK Town and Country Planning (Environmental Impact Assessment) Regulations 2011 SI 2011 No. 1824, where cumulative impacts are given different definitions. For example, Schedule 3, Section 1a, refers to them as those impacts which occur having regard, amongst other things, to the size of the development, while Section $1 \mathrm{~b}$ as those cumulating with other developments. These definitions lead one to infer that cumulative impacts are to be considered as impacts which occur across developments. However, Schedule 4 Part 1, which deals with information required in the environmental statements, defines these potential consequences as "a description of the likely significant effects of the development on the environment, which should cover the cumulative effects of the development", implying that they are impacts which accumulate within the life of the project (Cooper and Sheate, 2002). Such confusion as to what needs to be considered as a cumulative impact of a development could significantly affect an EIA 
undertaken on Poole Harbour. Depending on the interpretation of the practitioner, could result in potential impacts going unnoticed.

Another essential concept in nature conservation law is compensatory measures.

Should it be decided that a renewable energy development in Poole Harbour should be approved under grounds of 'imperative reasons of overriding public interest' (IROPI), per Art.6(4) of the Habitats Directive. It would then have to satisfy the conditions set out in the directive's guidance notes and compensatory measures must be implemented. This means that the UK would be required to provide compensatory habitat to protect the integrity of the Natura 2000 network (Ginige et al., 2011). However, the effectiveness of creating compensatory habitats in Poole Harbour can be questioned on the grounds that alternative habitats may not be sufficient to maintain species survival. Poole Harbour was designated because it supports species that are rare or unique in themselves. In order to comply with the Habitats Directive, compensation must be of equal or higher quality than the habitat it is replacing (MMO, 2011). Obviously, this is no easy feat and many studies have been undertaken to understand the implications of habitat compensation. The best example of habitat mitigation in the UK was the creation of intertidal mud flats in Teesmouth (Evans, 1998, cited by Atkinson, 2003) at Seal Sands through managed retreat. Here, it was found that, for the most part colonies could be re-established at new sites but there was a time lag of around three years (Atkinson, 2003). This is relevant to Poole Harbour's distinct environment which provides important habitats for vulnerable birdlife. Whilst there have been studies where habitat compensation in the USA has proved successful, the same rules are not as easily applicable in Poole Harbour, where intertidal habitats are far more diverse in terms of sediment sizes and tidal ranges (Atkinson et al., 2001). Therefore, it would make a difficult enterprise to secure compensatory habitats of an equal or better standard as required under the directive (Humphreys and May, 2005).

This leads the case for creating replacement habitat prior to starting development of the old site (Atkinson et al., 2001), thus embracing the precautionary principle and ensuring that there will be successful populations of the misplaced species. It is stated in the guidelines to the Habitats Directive that "a site should not be irreversibly affected by a project before the compensation is indeed in place" (European Commission, 2007), allowing for exceptions if it takes a long time to establish a new replacement habitat. As previously identified, there can be a time lag of up to three years to fully establish a working ecosystem.

If a project received approval, presumably there would be pressure to implement it as soon as possible. Therefore, it may be difficult to ensure that compensatory habitats are able to fulfil expectations. If it was the case that a scheme was in operation prior to the creation of compensatory habitat, the member state would be responsible to provide 'extra compensation' (that the compensation must be additional in relation to the Natura 2000 network to which the member state should have contributed in conformity with the Directives) [European Commission, (2007), p.13]. Added to this, the guidelines of the Directive suggest that if all these options cannot be fulfilled and development would affect rare species, the 'zero option' (withdrawal of the project) must be considered (European Commission, 2007).

Another area of UK legislation relevant to a proposed renewable energy project in Poole Harbour is the Marine and Coastal Access Act 2009 (MCAA). It contains important requirements designed to promote and maintain biodiversity in British waters, 
combining the protection of the marine environment with human health, prevention of interference with legitimate uses of the sea, (Section 69) and a strong emphasis on supporting renewable energy (s12) and marine economic zones (s116).

Besides all the above, it must be mentioned that much of the Harbour also lies within the Dorset Area of Outstanding Natural Beauty (AONB), which was designated in 1959 under the National Parks and Access to the Countryside Act 1949 to conserve and enhance the natural beauty of the site (Dorset Area of Outstanding Natural Beauty, 2012). In addition, Poole Harbour is a site of archaeological heritage interest that was recognised in 2003, when it was identified as a Wetland of National Importance by English Heritage in accordance with the National Heritage Act 2002 (Poole Harbour Aquatic Management Plan, 2011).

\subsection{Water pollution and quality}

In the UK, the Environment Agency (EA) is the statutory body responsible for managing the water resources, their quality and pollution control by virtue of s.2 of the Environment Act 1995 (EA, 1995). Water pollution and water quality is regulated by the Environmental Permitting (England and Wales) (Amendment) (No. 2) Regulations 2010, SI 2010/675 (EPR, 2010), the Water Industry Act 1991 as principally amended by the Water Industry Act 1999 and the Water Act 2003 together they provide the main regulatory controls in England and Wales.

The EA is charged with preventing deterioration of water quality and seeking its improvement; it has a duty to promote the conservation and enhancement of the water environment (inland and coastal waters). As well as pollution control, the agency's responsibilities include water resource management, planning and conservation, flood defence, forecasting and warning, abstraction licences, fisheries and in some areas navigation. It also has certain duties in relation to promoting conservation; amenity and recreational facilities. Besides the EA's regulatory functions at national level, its duties also embrace the UK's obligation under the Council Directive 2000/60/EC establishing a framework for Community action in the field of water policy (EU Water Framework Directive or WFD).

The WFD set, for the first time, legal standards for monitoring and reporting the health of water bodies throughout Europe (Bell and McGillivray, 2008). The ultimate goal of the legislation is that all European water bodies assessed should meet 'good ecological and chemical status' by 2015 , or must have management actively working to achieve this per Art. 4.1 WFD. The Directive, and the resulting domestic law (The Water Environment (Water Framework Directive) (England and Wales) Regulations 2003-S. I. 2003 No. 3242), applies to all terrestrial and groundwater including transitional (estuarine) and coastal waters (up to 1 nautical mile from the coast). WFD assessments are applicable to the waters in both estuaries and harbours, meaning that new developments should be able to demonstrate, prior to consent, that no detrimental impacts to the water quality could be reasonably foreseen by the proposed activity (MMO, 2012).

At a national level water management obligation under WFD is undertaken through River Basin Management Plans, which allows splitting into small catchments areas. (Article 4 WFD) The WFD takes a significant step towards integration of water protection and looks beyond immediate human interest in the protection of water considering living things dependant on water autonomously of human interest (Scott, 2009). Environmental Protection: European law and Governance. Oxford University 
Press, Oxford) Standardised methodologies and assessment tools are available to ensure consistency in monitoring (Bell and McGillivray, 2008). However, with the division of larger water bodies into catchments, there is much potential for conflicts between catchment objectives and land use and water quality (Moss, 2004).

The varied management objectives of the rivers discharging into Poole Harbour (Poole Harbour Aquatic Management Plan, 2011) may ultimately lead to alterations in the anthropogenic inputs which reach the harbour, thus impacting on primary production (Scanlan et al., 2007). As a heavily modified water body, Poole Harbour should be seeking to achieve 'good ecological potential', ultimately meaning no further declines in water quality (Uriarte and Borja, 2009). Specific considerations for the Poole Harbour PTEP proposal, under the WFD, should include avoidance of any activity that would permanently or periodically increase the rates of erosion, sedimentation or turbidity (Poole Harbour Aquatic Management Plan, 2011). Furthermore, it must be sensitive to the protection and promotion of salt marsh areas - as the decline of these has been linked to increased heavy metal presence, e.g., cadmium, in the harbour waters (Hübner et al., 2010). Finally, a full assessment of the likely impacts to both the biotic and abiotic components of this environment should be undertaken (MMO, 2012).

The requirements for the safe installation of a closed or open loop water source heat pump system (WSHC) vary according to the different technology and risk involved. These requirements are given by the EA in Environmental good practice guide for ground source heating and cooling, (EA, 2011).

The closed-loop heat pump systems do not currently necessitate any form of permission from the EA if located on a privately owned piece of land. But if the closed-loop scheme was to be put into, or adjacent to, a watercourse it may require a flood defence consent. Whilst the majority of close loops schemes are installed and operated with no harmful effect on the environment, owners and installers should bare in mind that they are liable for any adverse effects that the scheme may cause (EA, 2011). The potential types of risk of a closed WSHC system are discharge of a polluting substance (e.g., escape of circulating fluid) and changes of temperature in the water. In the first scenario, if the scheme leads to discharge of a polluting substance to controlled waters (including ground water), the drilling contractor, the installer, the owner or operator may be liable for prosecution under EPR 2010, Part 2, Chapter 1, Section 12(1) and Part 4, Section 38(1). In the second scenario, if the discharge or removal of heat by the system interferes with the environment features, actions might be brought against the operator of the scheme under the UK Law of Nuisance (Wolf and Stanley, 2011) and the EU Environmental Liability Directive (ELD) (Directive 2004/35/CE of the European Parliament and of the Council on environmental liability with regard to the prevention and remedying of environmental damage (Consolidated 01/05/2006) (ELD) (see Section 5.3 below).

The open loop WSHC system involves abstraction of water for heating and cooling purposes and will require an abstraction licence from the EA if the quantity abstracted is more than $20 \mathrm{~m}^{3} / \mathrm{d}$ in any 24 hour period (EA, 2010a). The water that emerges from the heat exchanger will most likely have changed its temperature. It will usually be warmer (in a cooling scheme) or colder (in a heating scheme) than the original water. This thermally changed water will be discharged into a surface water body (as defined in s.104 of the WRA 1991), in our case Poole Harbour, a natural water body. In order to obtain the required EA discharge consent permit, via the Environmental Permiting Regulations 
2010, the resulting water must not contain polluting chemicals, the temperature change must be less than $8^{\circ} \mathrm{C}$, the outlet temperature must not exceed $25^{\circ} \mathrm{C}$ and the discharge must be to the same water body from which the water was abstracted. Furthermore, the discharge "must not be made into fresh water within 500 metres upstream from a designated shellfish water, European site, Ramsar site, SSSI or any body of water identified as containing a protected species or within $100 \mathrm{~m}$ of a wild life site" (p.24). For a tidal water site the distance of $500 \mathrm{~m}$ for the discharge to take place means 'in any direction' to the nearest boundary of any of the sites mentioned above (pursuant of Chapter 4 of the EPR 2010 see EA (2010b).

\subsection{Environmental liability directive}

The EU's Directive 2004/35/CE of the European Parliament and of the Council on environmental liability with regard to the prevention and remedying of environmental damage (Consolidated 01/05/2006) (ELD) was transposed into UK legislation belatedly through the Environmental Damage (Prevention and Remediation) Regulations 2009 (SI 2009/153, as amended by SI 2009/3275) (EDR, 2009).

A key purpose of the regulation is to make the operator of an activity solely responsible for putting right any environmental damage, or threat of environmental damage (and the costs of so doing), caused by his activities - i.e., application of the polluter pays principle. The operator will also be liable for any remedial costs incurred by the enforcing authority unless he can demonstrate that the environmental damage (or threat of environmental damage) was caused by a third party (Bergkamp, 2002)

Environmental damage according to the EDR 2009 is damage caused by an activity listed in Schedule 2 to: protected species or natural habitats listed in the EU Birds Directive and the EU Habitats Directive - mainly those on Natura 2000 sites - and also to those on SSSI notified under the Wildlife and Countryside Act 1981.

EDR 2009 Schedule 1 details the threshold of damage for: species and habitats on and off SSSIs; surface water or ground water, including any adverse effect on the environment of surface or groundwaters resulting in the deterioration of status as defined in the WFD, whether ecological, chemical or quantitative; land where it relates to contamination which brings about a significant risk to human health or contamination through the introduction of organisms or micro-organisms. The activities causing damage are listed in Schedule 2 and include: permitted installations; waste management operations; mining waste; discharges requiring authorisation; water abstraction and impoundment; manufacture, use, storage, etc. of dangerous substances; plant protection products and biocidal products; transport of dangerous goods; contained or deliberate release of genetically modified organisms; and transboundary shipment of waste.

In the case of environmental damage to protected species, natural habitats or SSSIs, the EDR 2009 also covers damage caused by any other activity if the operator either intended to cause the damage or was negligent as to whether damage would be caused (Part 1 Section 5).

It excludes from its scope any environmental damage that took place before the EDR 2009 came into force (Part 1 Section 8 EDR 2009); environmental damage caused by oil pollution, in which liability or compensation falls within the scope of relevant international conventions such as the 1992 Protocol to the Convention on Civil Liability for Oil Pollution Damage; damage caused by radioactivity from an activity 
covered by the Treaty establishing the European Atomic Energy Community; environmental damage as a result of an 'act of terrorism', 'natural disasters' such as hurricanes or exceptional flooding (but regular seasonal flooding is not excluded), and damage caused by commercial sea fishing carried out in compliance with the Common Fisheries Policy.

The EDR 2009 also exempts damage to water caused by new modifications to the physical characteristics of a surface water body, alteration to the level of a body of groundwater, and deterioration from high to good status of a body of surface water resulting from new sustainable human development activities.

Under the EDR 2009 s20 (1) if relevant harm has occurred, the operator responsible must take remedial measures. If the primary remediation does not fully restore the damaged site, 'complementary' remediation must be undertaken, on the site or elsewhere, to compensate for that fact (EDR 2009 Schedule 4, Part 1, Section 5). 'Compensatory' remediation will also be required to make up for the interim losses during the period until the primary and complementary measures take effect. Guidance is given on the choice of measures and what is appropriate for complementary or compensatory remediation where direct equivalence is not possible. For conservation sites, the effect is that if a site is destroyed or cannot be wholly restored, then alternative or supplementary measures must be taken to provide the same overall conservation value, albeit not necessarily a direct equivalent to what has been lost, and before the damaged site is fully restored or a substitute provided, interim measures must be taken to make up for what is temporarily lost. Here, although the responsibility is on the operator to propose and undertake the remedial action, it is still the relevant 'competent authority' that determines what must actually be done (Reid, 2011).

To sum up, there are different levels of environmental legislation that protect Poole Harbour's biodiversity from the threat of antropogenic activities. This patchwork quilt of laws aim to conserve specifically: the wetland, intertidal and coastal habitats, resident and migratory wild birds, the natural beauty of the site, its archaeological relevance, the marine ecosystem and the water body itself autonomously of human interests. At the core of these laws is the need to promote a healthy marine ecosystem alongside minimal restrictions of human activities. This is achieved through site and species designations, regulations of the works and activities carried out in the Harbour, by placing legal obligations to those carrying activities within the site and by requiring EIA where there is risk of harm to the protected characteristics of the site. Furthermore, the law establishes a system of liability and compensation measures in the event of potential and actual damage to the environment.

These laws are indicative of the international and national recognition given to Poole Harbour's ecological features. They acknowledge the impact that human activities have on the natural environment and the need to promote sustainable interaction. Nevertheless, the discussion above demonstrates that, in certain provisions, the law seems to give adequate protection to the environment, whilst in others is restricting its effectiveness. It is suggested that this incongruency stems from the attempt to engage with what seem to be conflicting agendas: the safeguard of the environment on the one hand and antropogenic activities on the other, including the promotion of renewable energy. Although the latter results from the attempt to mitigate climate change, it carries the burden of this tension. 


\section{Spatial planning}

It is important to recognise that a key aspect to the implementation of any development project is the understanding of the legal framework, plans and policies for the control or management of development. (Moore, 2010). The merits or otherwise of a proposal will be examined, assessed, having regard to policies and plans, and determined by the granting or refusal of consent. In the context of coastal or marine works, the two main types of development consent required are:

1 planning permission for infrastructure to the boundary jurisdiction of the Local

Planning Authority [generally above the mean low water mark (MLWM)] under the Town and Country Planning Act 1990

2 a Marine Licence for works below mean high water springs (MHWS) under the Marine and Coastal Access Act 2009.

The two systems work independently of each other and are administered by Local Planning Authorities and the Marine Management Organisation (MMO), respectively. There is, however, a reciprocal system of consultation on development proposals. Applications for development will be determined in accordance with the Local Plan of the Local Planning Authority in the case of land-based development and in accordance with the relevant Marine Plan in the case of in and off-shore development. In locations where Marine Plans have yet to be produced, in the interim, direction on licensing decisions will be given by the Marine Policy Statement (MPS).

Focusing on the in-shore development of the Poole Harbour project, the construction, alteration or improvement of any works either in or over the sea or on or under the sea bed (including off-shore generating stations with a capacity between 1 and 100 megawatts) requires a marine licence. Generating stations of a greater capacity are deemed to be national significant infrastructure projects and are subject to a different system of consent under the Planning Act 2008.

\subsection{Stakeholder engagement}

Environmental management (and decision making) is as much about managing human activities as managing land and water, therefore requiring the effective engagement of all stakeholders (including government agencies, NGOs, the business community and the general public) in the process of information gathering and policy making. Engagement and participation engenders a sense of ownership of information and policymaking resulting in a common understanding of issues and a negotiated learning process. In the $\mathrm{UK}$, as in many countries, part of the political agenda for improving governance at national and local level is the promotion of community capacity building across a range of policy areas including spatial planning. Participation is an integral part of Strategic Environmental Assessment (SEA) Directive 2001/42/EC and EIA Directive and in many countries, including the UK, participation is a mandatory requirement for all planning decisions (Hodder et al., 2009).

Both the established terrestrial planning system and the emerging marine planning system seek to engage the local community and stakeholders at each stage of the planning process - from information gathering, plan and policy making to implementation. Both systems incorporate a Statement of Community Involvement or Statement of Public 
Participation which set out how local communities and stakeholders will be consulted, how they can be involved in the formulation, alteration and review of policies and the part they can play in consideration of applications for development. The development of The MPS, for example, was shaped through the involvement of stakeholders through regional and national workshops and consultations on firstly, a discussion paper, followed by a draft policy statement. The latter generated 126 responses across a range of sectors and comments were invited and received on the supporting documents (the appraisal of sustainability (including a strategic environmental assessment); habitats regulations assessment, impact assessment and equalities impact assessment screening) as well as on the draft policy statement. A summary document (HM Government, 2011) has been published which details the main changes made to the final MPS as a result of public consultation, parliamentary scrutiny, and the policy finalisation process. It also details key comments made that have not been implemented in the final text and reasons for this. One pertinent point of interest was the discussion on how the MPS will prioritise between differing policies and activities and the suggestion that there were implicit priorities in the draft policy statement which inferred that planning should allow or encourage certain activities over others. Comments by respondents to the consultation express a range of views including "too much focus on environmental aspects and not enough focus on socio-economic aspects; the environmental pillar not being given sufficient prominence" (HM Government, 2010). There were also requests for more clarity on how conflicts would be managed in the marine planning system.

\subsection{Integration of policy objectives}

Just as land use planning seeks to reconcile competing claims for the use of land, the marine planning system, as expressed in the MPS, seeks to "contribute to the achievement and integration of sectoral/activity specific policy objectives within a framework of economic, social and environmental considerations" (HM Government, 2011). With reference to Marine Plans, which will provide a locally relevant expression of policy, implementation and delivery, a key principle will be to promote compatibility and reduce conflict. Responding to the consultation respondents' comments on implicit policy priorities (HM Government, 2011), the government makes clear that the MPS does not prioritise one activity over another and relative priorities will be most appropriately determined through the marine planning process, taking into account a wide range of factors alongside UK policy objectives, including the specific characteristics of individual Marine Plan areas. On the question of clarity on the management of conflict, the government's response is that Marine Plans should identify areas of constraint and opportunity for a range of activities and that engaging local communities and stakeholders in all stages of the planning process engenders support for plan-led policies, can identify opportunities for compatible uses and minimises potential conflicts. Further, it emphasises the role of evidence in conflict resolution.

\section{Conclusions}

The above discussion acknowledges that in principle, CRE projects, such as the PTEP initiative, are an innovative and successful way to supply energy to homes and businesses 
on a small scale with a range of associated benefits for local people and ecosystems (Rogers et al., 2012). These type of projects require detailed consideration of financial and technological viability, as well as their potential impacts on the environment. Environmental impacts assume even greater importance when the environment into which the development is introduced is valued for its habitats, species and amenity, particularly, as is the case with significant areas of Poole Harbour, it is subject to statutory designations and legal protection.

Crucial, therefore, to consideration of the Poole Harbour case study, given the government's twin objectives of mitigating climate change through the promotion of renewable energy and sustaining and enhancing biodiversity, is the capability of decision makers to integrate or reconcile these two policy objectives. The question is not whether one policy objective should take precedence over another, but whether spatial planners can work with engineers, ecologists, economists, environmental lawyers, the public and other stakeholders to gather robust evidence to realise renewable energy opportunities with minimal impact to species, habitats or ecosystems.

\section{Acknowledgements}

We would like to take this opportunity to thank Helena Batlle Argimon, Ann Thornton Roger Herbert for their help and contribution to this work.

\section{References}

Atkinson, P.W. (2003) 'Can we recreate or restore intertidal habitats for shorebirds?', Wader Study Group Bulletin, Vol. 100, pp.67-72.

Atkinson, P.W., Crooks, S., Grant, A. and Rehfisch, M.M. (2001) 'The success of creation and restoration schemes in producing intertidal habitat suitable for waterbirds', English Nature Research Report 425, English Nature, Peterborough.

Barrow, C.J. (2006) Environmental Management for Sustainable Development, 2nd ed., Routledge: Abingdon, Oxon.

Bell, S. and McGillivray, D. (2008) Environmental Law, 7th ed., Oxford University Press, Oxford.

Bentham, J. (1907) 'An introduction to the principles of morals and legislation', Library of Economics and Liberty [online] http://www.econlib.org/library/Bentham/bnthPML.html (accessed 28 August 2012).

Bergkamp, L. (2002) 'The proposed environmental liability directive', European Energy and Environmental Law Review, Vol. 11, No. 11, pp.294-314.

Cooling, P. (2011) Securing Energy from Tidal Streams in Poole Harbour. Borough of Poole, Environment Overview and Scrutiny Committee Meeting, Poole, 24 March [online] http://www.google.co.uk/url?sa=t\&rct=j\&q=\&esrc=s\&source

=web\&cd=1\&ved=0CFIQFjAA\&url=http\%3A\%2F\%2Fha2.boroughofpoole.com $\% 2$ Fakspool e\%2Fimages\%2Fatt5426.doc\&ei=GWEgUOyRFunO0QXmxoDYAg\&usg=AFQjCNHjxxww 1fXfO5FH2o4NRRqv461k1g (accessed 25 July 2012).

Cooper, L. and Sheate, W. (2002) 'Cumulative effects assessment: a review of UK environmental impact statements', Environmental Impact Assessment Review, Vol. 22, No. 4, pp.415-439 [online] http://www.sciencedirect.com (accessed 2 July 2012).

Crawford, J. and French, W. (2008) 'A low-carbon future: spatial planning's role in enhancing technological innovation in the built environment', Energy Policy, Vol. 36, No. 12, pp.4575-4579. 
DECC (2010) 'Severn tidal power feasibility study - phase 2, impact assessment' [online] http://wwwdecc.gov.uk/EN/Defaultaspx?n1=3\&n2=51\&n3=58\&n4=60\&n5=171 (accessed 30 March 2012).

DECC (2011a) 'UK renewable energy roadmap' [online] http://www.decc.gov.uk/assets/decc/11/meeting-energy-demand/renewable-energy/2167-ukrenewable-energy-roadmap.pdf (accessed 27 July 2012).

DECC (2011b) 'Renewable heat incentive scheme Q\&' [online] http://www.decc.gov.uk/assets/decc/what\%20we\%20do/uk\%20energy\%20supply/energy\%20 mix/renewable\%20energy/policy/renewableheat/1393-rhi-faqs.pdf (accessed 28 July12).

DECC (2012) 'Renewable energy' [online] http://www.decc.gov.uk/en/content/cms/meeting_energy/renewable_ener/renewable_ener.aspx (accessed 30 March 2012).

Department of Trade and Industry (2000) Community Involvement in Renewable Energy Projects AGuide for Community Groups, ETSU K/GE/00014/36/REP, DTI, London.

Dincer, I. (2000) 'Renewable energy and sustainable development: a crucial review', Renewable and Sustainable Energy Reviews, Vol. 4, No. 2, pp.157-175.

Dorset Area of Outstanding Natural Beauty (2012) Annual Review 2010-2011 [online] $\mathrm{http}: / /$ www.dorsetaonb.org.uk/assets/downloads/Annual_Review/20102011\%20annual\%20review\% 20a4\%20print\%20version.pdf (accessed 25 July 2012).

Dorset Energy Partnership (DEP) (2012) Bournemouth, Dorset and Poole 'Renewable Energy Strategy to 2020 [online] http://www.dorsetforyou.com/media.jsp?Mediaid=171439\&filetype=pdf (accessed 26 July 2012).

Durell, S.E.A.L.V.D., Stillman, R.A., Caldow, R.W.G., McGrorty, S. and West, A.D. (2006) 'Modelling the effect of environmental change on shorebirds: a case study on Poole Harbour, UK', Biological Conservation, Vol. 131, No. 3, pp.459-473.

E-mail from Hadley (2012a) A to Frazer Ball, 27 July 2012.

E-mail from Hadley (2012b) A to Tilak Ginige, 2 August 2012.

English Nature (1990) Poole Harbour Site Status [online] http://www.english-nature.org.uk/citation/citation photo/1000110.pdf (accessed 24 July 2012).

Environment Agency (EA) (2010a) Managing Water Abstraction, June, Environment Agency, Bristol [online] http://publications.environment-agency.gov.uk/PDF/GEHO0310BSBH-EE.pdf (accessed July 2012).

Environment Agency (EA) (2010b) Standard Rules SR2010No2 - Discharge to Surface Water: Cooling Water and Heat Exchangers, Environment Agency, Bristol [online] http://www.environment-agency.gov.uk/static/documents/Business/SR2010No2.pdf (accessed July 2012).

Environment Agency (EA) (2011) Environmental Good Practice Guide for Ground Source Heating and Cooling, Environment Agency, Bristol [online] http://www.environment-agency.gov.uk/business/topics/128133.aspx (accessed July 2012).

European Commission (2000) Managing Natura 2000 Sites: The Provisions of Article 6 of the 'Habitats' Directive 92/43/EEC, Office for Official Publications of the European Communities, Luxembourg.

European Commission (2007) Guidance document on Article 6(4) of the 'Habitats Directive' 92/43/EEC, Clarification of the Concepts of: Alternative Solutions, Imperative Reasons of Overriding Public Interest, Compensatory Measures, Overall Coherence, Opinion of The Commission, European Commission, Brussels.

Forsen, M. (2005) Heat Pumps-Technology and Environmental Impact (Part 1), Report Swedish Heat Pump Association, Sweden. 
Gazo, F. and Lind, L. (2010) 'Low enthalpy geothermal energy', Technology Review, GNS Science Report 2010/20, 58 p.

Gazo, F., Cox, B., Crookshanks, C. and Wilkinson, B. (2011) 'Low enthalpy geothermal energy', Technological Economics Review.

Ginige, T.A., Thornton, A. and Ball, F. (2011) 'The Severn tidal barrage project: a legal paradox?', Journal of Water Law, Vol. 21, No. 2, pp.66-77.

Guardian (2012) 'Sustainable development flourishing in Wales's green economy' [online] http://thinktosustain.com/marketspace/2012/05/sustainable-development-flourishing-inwaless-green-economy/ (accessed 31 July 2012).

Herbert, R.J.H., Kathryn, R., Hübner, R. and Stillman, R.A. (2010) 'Intertidal invertebrates and biotopes of Poole Harbour SSSI and survey of Brownsea Island Lagoon', March, Report to Natural England. Centre for Conservation Ecology \& Environmental Change, Bournemouth University, Poole.

HM Government (2010) An Initial Summary of Responses to the UK Marine Policy Statement: A Draft for Consultation, November [online]

http://archive.defra.gov.uk/corporate/consult/marine-policy/100721-marine-policyresponses.pdf (accessed 3 August 2012).

HM Government (2011) UK Marine Policy Statement, March, The Stationery Office, London [online] http://archive.defra.gov.uk/environment/marine/documents/interim2/mps-differencefrom-draft.pdf (accessed 3 August 2012).

HM Treasury (2011) The Green Book. Appraisal and Evaluation in Central Government [online] http://www.hm-treasury.gov.uk/d/green_book_complete.pdf (accessed 27 July 2012).

Hodder, K.H., Sharp, R.J.A., Perrella, L., Butters, J., Kenward, R.E. and Ewald, J. (2009) 'D3.3 synthesis report: Central and local information flows and decision making requirements', [Report to the European Commission from FP-7 project \#212304 for a Transactional Environmental Support System]. European Commission, 92pp. (Transactional Environmental Support System. Deliverable D3.3).

Hübner, R., Herbert, R.J.H. and Astin, K.B. (2010) 'Cadmium release caused by the die-back of the salt marsh cord grass /Spartina anglica/ in Poole Harbour (UK)', Estuarine, Coastal and Shelf Science, Vol. 87, No. 4, pp.553-560.

Humphreys, J. and May, V. (2005) The Ecology of Poole Harbour, pp.163-174, Elsevier, Amsterdam.

JNCC (2008) Information Sheet on Ramsar Wetlands: UK11054 Poole Harbour Designation, March 1999 [online] http://jncc.defra.gov.uk/pdf/RIS/UK11054.pdf (accessed 4 July 2012).

Jones, K. (2011) 'Marine energy...but not what you think!' [online] http://ntenvironmentalwork.net/2011/12/02/marine-energy-but-not-what-you-think/ (accessed 31 July 2012).

Jordan, A. and O'Riordan, T. (1995) 'The precautionary principle in UK Environmental Law and Policy', in UK Environmental Policy in 1990s, pp.70-71, St Martin's Press, New York.

Julius, S. (2012) Marine Renewable Energy Feasibility - Poole Harbour Case Study, Dissertation, School of Applied Sciences, Bournemouth University, Poole.

Kensa Engineering Ltd. (2009) Fact Sheet - Energy Sources - 1.0 [online] http://www.kensaengineering.com/Library/Fact-sheets/energysources.pdf (accessed 28 July 2012).

Kramer, L. (2009) 'The European Commission's opinions under Article 6(4) of the Habitats Directive', Journal of Environmental Law 2009, Vol. 21, No. 1, pp.59-85.

Langston, W.J., Chesman, B.S., Burt, G.R., Hawkins, S.J., Readman, J. and Worsfold, P. (2003) 'Characterisation of the South West European Marine Sites: Poole Harbour SPA', Occasional Publications, Marine Biological Association of the United Kingdom, No. 12, 163p.,

Liley, D. and Clarke, R.T. (2003) 'The impact of urban development and human disturbance on the numbers of nightjar Caprimulgus europaeus on heathlands in Dorset, England', Biological Conservation, Vol. 114, No. 2, pp.219-230. 
Marine Management Organisation (MMO) (2011) 'Guidance on imperative reasons of overriding public interest under the Habitats Directive' [online] http://www.marinemanagement.org.uk/licensing/supporting/documents/iropi.pdf (accessed 9 August 2012).

Marine Management Organisation (MMO) (2012) Port of Poole Master Plan - Screening and Scoping Opinion, Major Infrastructure Projects Team, Newcastle Upon Tyne [online] http://Marinemanagement.Org.Uk/Licensing/Public_Register/Harbour/Documents/ Poole_Screening_Scoping2.Pdf (accessed 2 August 2012).

Masden, E.A., Fox, A.D., Furness, R.W., Bullman, R. and Haydon, D.T. (2010) 'Cumulative impact assessments and bird/wind farm interactions: developing a conceptual framework', Environmental Impact Assessment Review, Vol. 30, No. 1, pp.1-7.

Miller, G.T. (2006) Environmental Science, Thompson Learning, London, UK.

Moore, V. (2010) A Practical Approach to Planning Law, Oxford University Press, Oxford.

Moss, T. (2004) 'The governance of land use in river basins: prospects for overcoming problems of institutional interplay with the EU Water Framework Directive', Land Use Policy, Vol. 21, No. 1, pp.85-94.

Natural England (2010) 'European Marine Site Risk Review - Poole Harbour site plan, November [online] http://archive.defra.gov.uk/environment/marine/documents/interim2/poolesiteplan.pdf (accessed 3 August 2012).

NIBE (2012) 'Ground source heat pumps with 5 kilometres of piping produce heat from ice-cold sea' [online] http://www.nibe.eu/Domestic-heatingcooling/Ground-source-heatpumps/Referenser/5-kilometres-of-piping-produce-heat-from-ice-cold-sea/ (accessed 30 July 2012).

Pearce, D. (2012) Testing the SRM Theory: Are Artificial Habitats Favouring Invasive Species?, Dissertation, School of Applied Sciences, Bournemouth University, Poole.

Peel, J. (2004) 'Precaution - a matter of principle, approach or process?', Melbourne Journal of International Law, Vol. 19, No. 5(2), p.483.

Poladitis, H., Haralambopoulos, D.A., Munda, G. and Vreeker, R. (2006) 'Selecting an appropriate multi-criteria decision analysis technique for renewable energy planning', Energy Sources, Part B, Vol. 1, No. 1, pp.181-193.

Polagye, B., Van Cleve, B., Copping, A. and Kirkendall, K. (Eds.) (2011) Environmental Effects of Tidal Energy Development, NOAA Technical Memo, F/SPO-116, US Department of Commerce, Washington, DC.

Poole Harbour Aquatic Management Plan (2011) Poole Harbour Aquatic Management Plan $2006-$ Amended 2011 [online] http://www.pooleharbouraqmp.co.uk/pdf/Poole\%20Harbour_Aquatic_ Management_Plan_2011_Update.pdf (accessed 4 January 2012 and 4 July 2012).

Poole Harbour Commissioners (2011) Poole Harbour Draft Management Plan [online] http://www.phc.co.uk/masterplan/_downloads/phc-masterplan.pdf (accessed 25 July 2012).

Presnell, K. (1996) 'A utilitarian view of renewables', Fuel and Energy Abstracts, Vol. 37, No. 4, pp.276-276(1).

Reid, C.T. (2011) 'The privatisation of biodiversity? Possible new approaches to nature conservation law in the UK', Journal of Environmental Law, Vol. 23, No. 2, p.203.

Renewable Energy Directive (2009) [online] http://eur-lex.europa.eu/JOHtml.do?uri=OJ:L:2009:140:SOM:EN:HTML (accessed 30 March 2012).

Rio Declaration on Environment and Development (1992) U.N. Conference on Environment and Development, 46th Sess., Agenda Item 9, princs. 10 and 17, at 3, 4, U.N. Doc. A/CONF. 151/5/Rev. 1, 31 I.L.M. 874, 878, 879.

Rogers, J.C., Simmons, E.A., Convery, I. and Weatherall, A. (2008) 'Public perceptions of opportunities for community-based renewable energy projects', Energy Policy, Vol. 36, No. 11, pp.4217-4226. 
Rogers, J.C., Simmons, E.A., Convery, I. and Weatherall, A. (2012) 'Social impacts of community renewable energy projects: findings from a wood fuel case study', Energy Policy, Vol. 42, pp.239-247.

Scanlan, C.M., Foden, J., Best, M.A. and Wells, E. (2007) 'The monitoring of opportunistic macroalgal blooms for the Water Framework Directive', Marine Pollution Bulletin, Vol. 55, Nos. 1-6, pp.162-171.

Scott, J. (2009) Environmental Protection: European law and Governance, Oxford Universty Press, Oxford

Shackley, S. and Green, K. (2007) 'A conceptual framework for exploring transitions to decarbonised energy systems in the United Kingdom', Energy, Vol. 32, No. 3, pp.221-236.

Turnpenny, A.W.H., Seaby, R.M.H., Nedwell, J.R. and Needham, K. (1995) 'Measurements of sound propagation from a seismic airgun array in Poole harbour and Bay', Subacoustech Report No. 125R0301, Southampton, Hampshire.

United Nations World Commission on Environment and Development (UNWCED) (1987) Our Common Future, (Brundtland Report), Oxford University Press, Oxford.

Uriarte, A. and Borja, A. (2009) 'Assessing fish quality status in transitional waters, within the European Water Framework Directive: setting boundary classes and responding to anthropogenic pressures Estuarine', Coastal and Shelf Science, Vol. 82, No. 2, pp.214-224.

Walker, G. (2008) 'What are the barriers and incentives for community-owned means of energy production and use?', Energy Policy, Vol. 36, No. 12, pp.4401-4405.

Weiss, E.B. (1984) 'The planetary trust: conservation and intergenerational equity', Ecology Law Quarterly, Vol. 11, No. 4, p.495.

Wolf, S. and Stanley, N. (2011) Wolf and Stanley on Environment, 5th ed., Routledge, Abingdon, Oxon.

Woodruff, A. (2007) 'An economic assessment of renewable energy options for rural electrification in Pacific Island countries’ [online] http://www.SOPAC.org/ (accessed 31 July 2012). 